\title{
Game Edukasi Mengenal Huruf Katakana dan Hiragana Berbasis Android
}

\author{
Agus Gede Adi Prayoga ${ }^{1}$, I Putu Agung Bayupati ${ }^{2}$, A. A. K. Agung Cahyawan W. ${ }^{3}$ \\ Jurusan Teknologi Informasi, Fakultas Teknik, Universitas Udayana \\ Jalan Kampus Bukit Jimbaran, Bali, Indonesia \\ 1adiyoga666@gmail.com \\ 2bayuhelix@yahoo.com \\ 3a.cahyawan@yahoo.com
}

\begin{abstract}
Abstrak
Bahasa Jepang merupakan bahasa yang berbeda dengan bahasa lain pada umumnya karena penulisannya menggunakan huruf Katakana dan Hiragana. Kebutuhan akan bahasa Jepang sangat beragam terutama dalam berkomunikasi contohnya menyambut wisatawan. Pembelajaran bahasa Jepang di Indonesia menemui beberapa kendala diantaranya kurangnya sarana pembelajaran serta suasana belajar yang cenderung membosankan sehingga banyak siswa mengalami kesulitan belajar. Game edukasi pada perangkat mobile merupakan metode pembelajaran baru yang dinilai dapat lebih menarik minat seseorang untuk belajar. Game Edukasi Mengenal Huruf Katakana dan Hiragana dibuat bertujuan membantu mengatasi kesulitan belajar bahasa Jepang terkait penguasaan huruf Katakana dan Hiragana. Materi yang disisipkan dalam game bersumber dari kurikulum Ni Hon Go No Kyoukasho dan Ni Hon Go 1. Game memiliki tiga fitur pembelajaran diantaranya tabel, menulis dan tebak huruf serta fitur permainan sebagai hiburan. Berdasarkan hasil kuesioner 30 siswa yang mengalami kesulitan belajar bahasa Jepang, sebanyak 60\% responden menyatakan game mudah dipahami sebagai media pembelajaran bahasa Jepang.
\end{abstract}

Kata kunci : Bahasa Jepang, Katakana Hiragana, Kesulitan belajar, Game edukasi.

\begin{abstract}
Japanese language is different from other language in general, because in its writing is using Katakana and Hiragana letter. The use of Japanese is in various need, especially in communication for example entertaining tourists. Japanese language learning in Indonesia facing several problems among other are lack of infrastructure in practicing and also boring atmosphere which make students having difficulty in learning. Educational game application for mobile device is a new learning method is considered as a tool to attract one's interest to learn. Educational Games to Indentify Katakana and Hiragana Letter is created in order to help to overcome the difficulty in learning Japanese Language relate to mastery Katakana and Hiragana letter. Learning material which is implied in the game came from Ni Hon Go 1 and Ni Hon Go No Kyoukasho curriculum. Game have three learning features such as table, letter writing and guessing, there are also entertaining addition features. Based on questionnaire data result on 30 students having difficulty in learning Japanese language, as much as $60 \%$ of respondents say that the game was easily understood as a Japanese language learning media.
\end{abstract}

Keywords : Japanese Language, Katakana Hiragana, Learning difficulty, Educational game.

\section{Pendahuluan}

Kebutuhan penguasaan bahasa Jepang di Indonesia sudah menjadi prioritas yang harus dipenuhi karena kegunaannya dalam berbagai hal seperti adanya beasiswa melanjutkan studi di Jepang, menyambut wisatawan Jepang dan lain-lain. Hal ini dapat dilihat dengan 
ditambahkannya pelajaran bahasa Jepang ke dalam kurikulum beberapa sekolah umum, selain itu banyak terdapat kursus bahasa Jepang di Indonesia. Bahasa Jepang juga menjadi ketertarikan bagi masyarakat Indonesia, budaya Jepang sekarang sedang banyak digemari seperti kartun dan anime Jepang. Bahasa Jepang menggunakan kata sandi yang berbeda yaitu berupa huruf Hiragana dan Katakana, perbedaannya terdapat pada segi bentuk huruf, tata cara pengucapan dan penulisan. Huruf Hiragana digunakan untuk menuliskan kata asli bahasa Jepang contohnya kata daging ditulis niku $(に<)$ sedangkan huruf Katakana digunakan untuk menuliskan kata serapan dari bahasa asing contohnya kata keju ditulis chiizu (チイズ).

Hal yang paling penting dalam mempelajari bahasa Jepang yaitu mengenal baik huruf Katakana dan Hiragana. Proses pembelajaran bahasa Jepang di Indonesia masih sering menemui beberapa kendala pada hal tersebut. Menurut hasil dari penelitian yang dilakukan oleh Kurniah mengenai faktor yang menyebabkan kesulitan belajar bahasa Jepang diantaranya, siswa jarang belajar melatih menulis huruf Katakana dan Hiragana sehingga tidak dapat mengingat dan membedakan bentuk huruf yang mirip [1]. Berdasarkan hal tersebut, diperlukan suatu media pembelajaran baru yang dapat membantu siswa dalam belajar melatih menulis dan menghafal huruf Katakana dan Hiragana.

Perkembangan teknologi saat ini dapat dimanfaatkan untuk mengembangkan aplikasi pada perangkat mobile dalam membantu proses pembelajaran, seperti game edukasi. Banyaknya penggunaan berbagai aplikasi mobile saat ini mendukung dalam penerapan game edukasi pada perangkat mobile sebagai media pembelajaran, yang tentunya lebih mudah diterima serta lebih efisien waktu karena dapat digunakan dimanapun dan kapanpun melalui perangkat mobile. Penelitian mengenai media pembelajaran pada perangkat mobile pernah dibahas sebelumnya oleh Setiyawan [2]. Fitur pembelajaran aksara Bali oleh Setiyawan menggunakan fitur tebak huruf dan menulis, perbedaannya dengan penelitian ini yaitu pada fitur menulis dibuat lebih kompleks dengan adanya tanda-tanda dalam menulis serta materi dalam game mengacu pada kurikulum pelajaran sekolah. Penelitian yang sama membahas mengenai media pembelajaran pada perangkat mobile dengan materi berdasarkan kurikulum, dibahas oleh Belkhouche [3]. Penelitian oleh Habgood menyatakan konsep motivasi intrinsik pada konten game membuat anak belajar lebih efektif, tetapi dalam penelitian ini digunakan konsep motivasi ekstrinsik yaitu fitur skor dalam game sebagai reward yang dapat memacu pengguna untuk lebih giat berlatih dalam memperoleh skor yang tertinggi [4].

Android merupakan salah satu sistem operasi pada smartphone yang berkembang pesat saat ini. Fitur touchscreen pada smartphone berbasis Android, mendukung pembuatan game edukasi bahasa Jepang ini dengan fitur menyusun dan menulis huruf-huruf Jepang pada perangkat mobile. Adanya kedua fitur tersebut serta game yang dibuat pada perangkat mobile sebagai media pembelajaran, nantinya game dapat membantu dalam mengatasi kesulitan belajar bahasa Jepang yang disebabkan oleh faktor-faktor di atas.

\section{Metodologi Penelitian}

Game Edukasi Mengenal Huruf Katakana dan Hiragana ini merupakan game yang bertujuan sebagai sarana pendidikan mengenai dasar-dasar dalam mempelajari bahasa Jepang yaitu huruf Katakana dan Hiragana yang nantinya dapat mampu mempermudah pengguna dalam proses belajar dengan fitur game yang mudah digunakan sehingga dapat mengatasi kesulitan belajar bahasa Jepang.

Use Case Diagram pada Gambar 1 merupakan salah satu diagram UML sebagai pemodelan sistem yang digunakan untuk mengilustrasikan arsitektur atau gambaran umum dari game edukasi ini. Use Case Diagram menunjukkan interaksi antara actor/user dengan fungsi yang terdapat pada sistem game edukasi ini. Terdapat empat pilihan menu utama dalam game yaitu bermain, belajar, tutorial dan skor. Dua elemen utama yang ditekankan dalam game yaitu fitur belajar sebagai media pembelajaran dan fitur bermain sebagai hiburan sekaligus sebagai media untuk menguji kemampuan pengguna setelah belajar. Kedua elemen utama ini diimplementasikan kedalam menu utama game yaitu menu belajar dan bermain.

Actor yang memilih menu atau fungsi utama belajar maka didalamnya terdapat tiga pilihan fungsi lagi diantaranya tabel untuk melihat tabel huruf Katakana dan Hiragana, menulis untuk 
berlatih menulis huruf dan tebak huruf untuk melatih pengguna menghafal huruf. Fitur menulis dalam game ini berisi tanda-tanda menulis yang muncul sebagai acuan dalam menulis huruf yang benar. Tata tulis huruf dalam game ini mengacu pada sumber referensi yaitu buku pelajaran bahasa Jepang dengan kurikulum Ni Hon Go 1. Actor yang memilih fungsi bermain maka didalamnya terdapat delapan buah pilihan level untuk bermain. Informasi mengenai cara bermain terdapat pada fungsi tutorial dan untuk melihat skor hasil bermain game dapat dilihat pada fungsi skor.

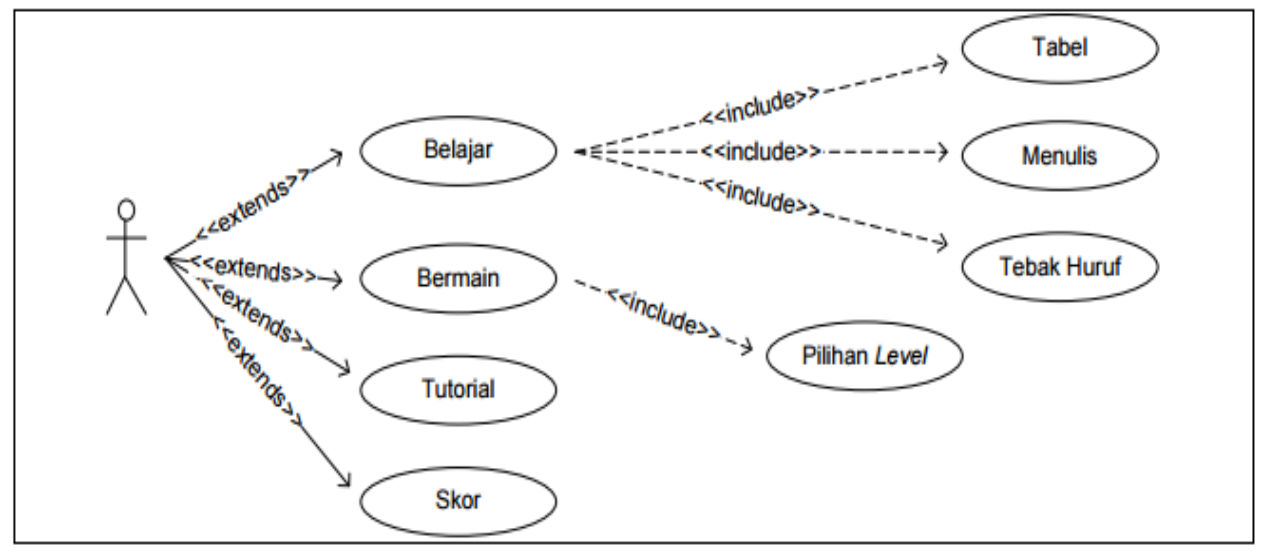

Gambar 1. Diagram Use Case game edukasi Mengenal Huruf Katakana dan Hiragana

Selain Use Case Diagram, untuk pemodelan game ini menggunakan Activity Diagram yang juga merupakan salah satu dari Diagram UML. Berikut ini merupakan activity diagram pada fitur menulis dan bermain.

Gambar 2(a) menunjukkan activity diagram antara user dan sistem pada menu belajar pilihan fitur menulis. Alur pada fitur menulis ini dimulai dari user menjalankan game kemudian sistem merespon dengan menampilkan menu utama pada game. User dapat memilih menu utama Belajar untuk menggunakan fitur menulis atau pilihan keluar dari game. Sistem merespon kembali dengan menampilkan tiga pilihan fitur yang terdapat pada menu utama Belajar. Fitur menulis dapat digunakan user dengan memilih pilihan menu menulis dari ketiga pilihan menu yang ada atau pilihan kembali ke menu utama game. Sistem menampilkan pilihan dua jenis huruf Katakana atau Hiragana pada fitur menulis. User dapat memilih salah satu jenis huruf kemudian sistem menampilkan scene yang berisi template huruf untuk ditulis. Sistem menampilkan tanda benar kemudian muncul template huruf berikutnya jika user telah menulis huruf dengan benar.

Gambar 2(b) menunjukkan activity diagram antara user dan sistem pada menu bermain. Alur pada fitur bermain ini dimulai dari user menjalankan game kemudian sistem merespon dengan menampilkan menu utama pada game. Fitur bermain dapat digunakan user dengan memilih menu utama Bermain atau pilihan keluar dari game. Selanjutnya sistem menampilkan scene yang berisi tampilan beberapa level pada game. User memilih level lalu sistem menampilkan scene permainan menyusun huruf. Huruf-huruf yang ada harus disusun user sesuai kata yang muncul dengan melakukan drag and drop huruf kemudian sistem melakukan pengecekan terhadap jawaban. User yang salah menjawab dapat mengulangi menyusun huruf sedangkan jika jawaban user benar dapat melanjutkan kata berikutnya.

Terdapat delapan buah level pada fitur bermain game ini yang memiliki tema berbeda tiap level dan mengacu pada sumber referensi buku pelajaran bahasa Jepang dengan kurikulum Ni Hon Go No Kyoukasho. Level 1 membahas tema angka, level 2 membahas tema warna, level 3 membahas tema anggota badan, level 4 membahas tema barang, level 5 membahas tema pakaian, level 6 membahas tema binatang, level 7 membahas tema hari dan level 8 membahas tema makanan dan minuman. 


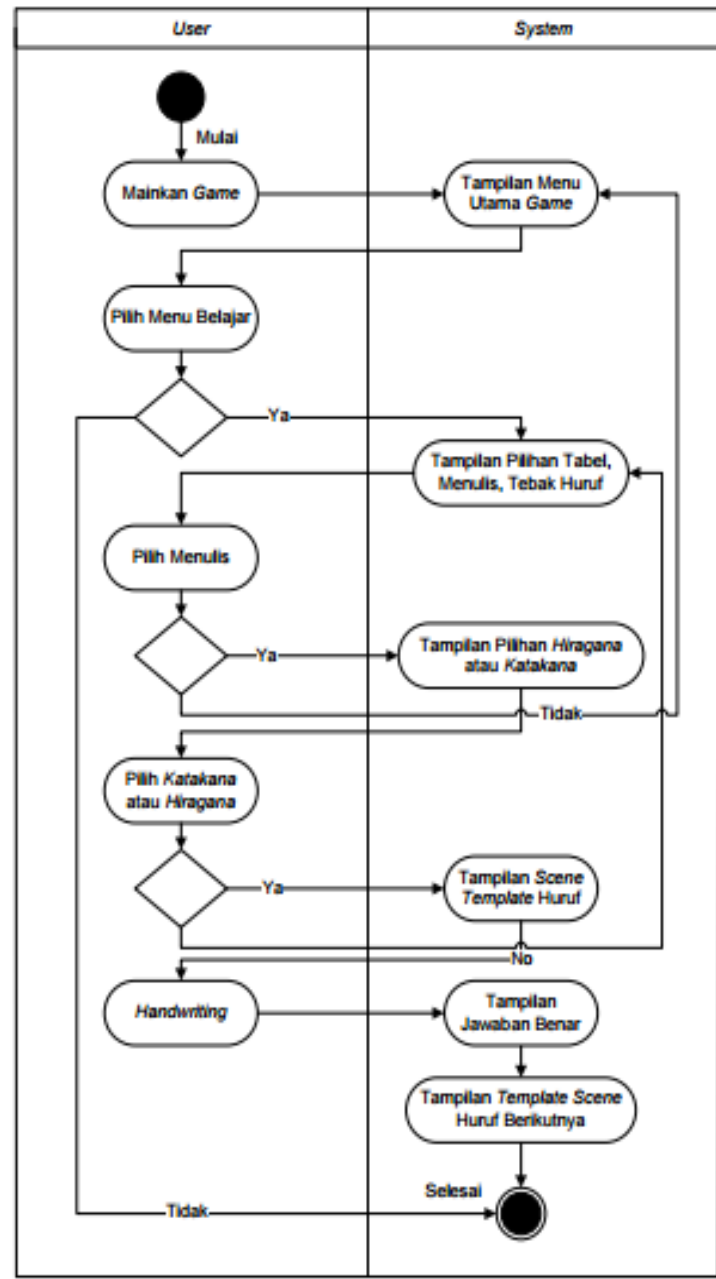

(a)

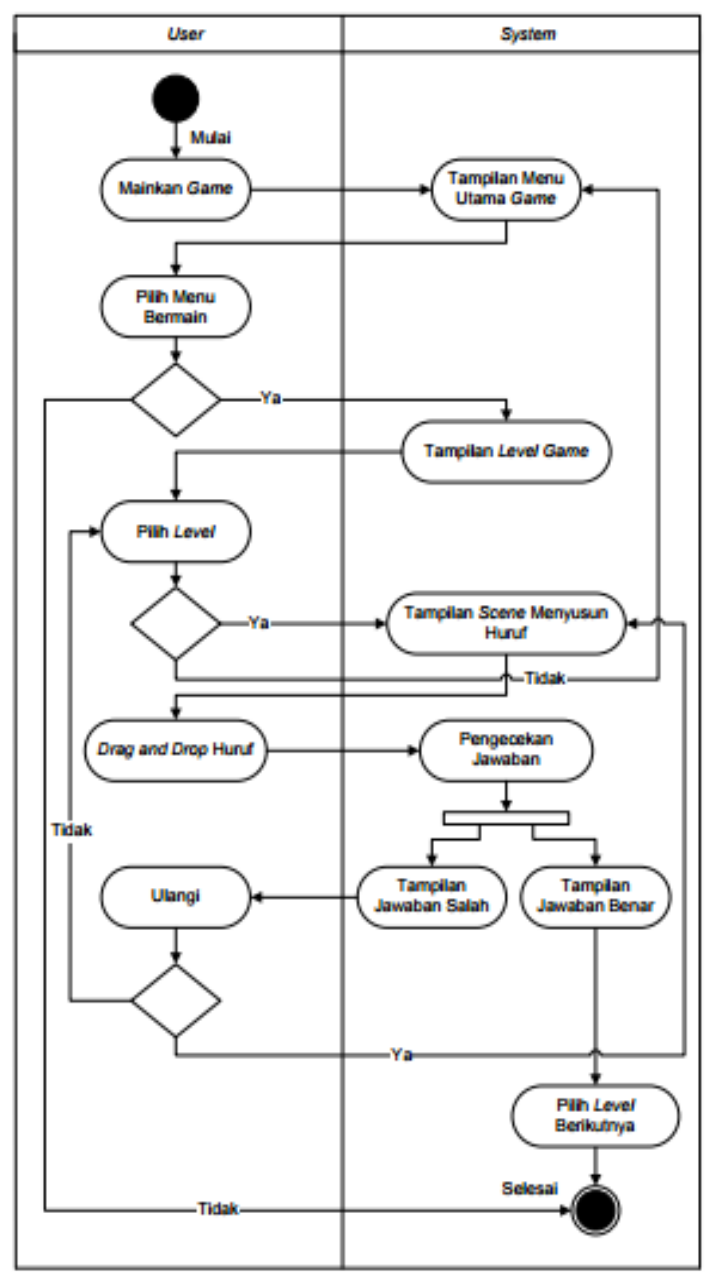

(b)

Gambar 2. (a) Activity Diagram fitur menulis (b) Activity Diagram fitur bermain

\section{Kajian Pustaka}

Pada bab ini menjelaskan kajian pustaka yang digunakan sebagai acuan dalam penelitian.

\subsection{Aksara Jepang}

Tulisan Jepang awalnya berasal dari tulisan China karena sebelumnya orang Jepang tidak memiliki sistem penulisan sendiri. Tulisan Jepang terbagi menjadi tiga yaitu Aksara Kanji (漢字), Aksara Hiragana (ひらがな), dan Aksara Katakana (カタカナ) [5]. Aksara Hiragana dan Katakana biasa disebut Kana. Aksara Hiragana umumnya digunakan untuk menulis kata-kata asli bahasa Jepang seperti menulis akhiran kata, kata keterangan, dalam situasi formal, bacaan anak-anak seperti komik, juga dalam membaca huruf kanji. Aksara Katakana biasanya digunakan untuk menulis kata-kata serapan yaitu kata yang berasal dari bahasa asing yang sudah diserap ke dalam bahasa Jepang.

Bentuk-bentuk dari huruf aksara Hiragana dan Katakana dapat dilihat pada Gambar 3, masingmasing huruf memilik bentuk yang berbeda. Huruf Hiragana memiliki bentuk sangat halus sedangkan huruf Katakana memiliki bentuk tegak dan lurus. Huruf Hiragana dan Katakana masing-masing berjumlah 46 huruf. Huruf Hiragana Katakana dapat dimodifikasi dengan menambahkan tanda tertentu atau menggabungkannya dengan huruf lain sehingga menghasilkan bunyi yang berbeda. Bunyi tersebut disebut bunyi Dakuon dan bunyi Yoon. 
a. Huruf Dakuon

Bunyi Dakuon adalah bunyi huruf Hiragana Katakana dasar dengan menambahkan tanda tenten (" ) yaitu tanda titik dua yang diletakkan di sebelah kanan atas huruf Hiragana Katakana dasar dan tanda maru $\left({ }^{\circ}\right)$ yaitu tanda lingkaran kecil yang diletakkan di sebelah kanan atas huruf Hiragana Katakana dasar. Huruf-huruf dasar yang menggunakan tanda tenten adalah huruf ka menjadi ga, sa menjadi za, ta menjadi da dan ha menjadi ba sedangkan huruf dasar yang menggunakan [ ${ }^{\circ}$ ] tanda maru adalah huruf ha menjadi pa.

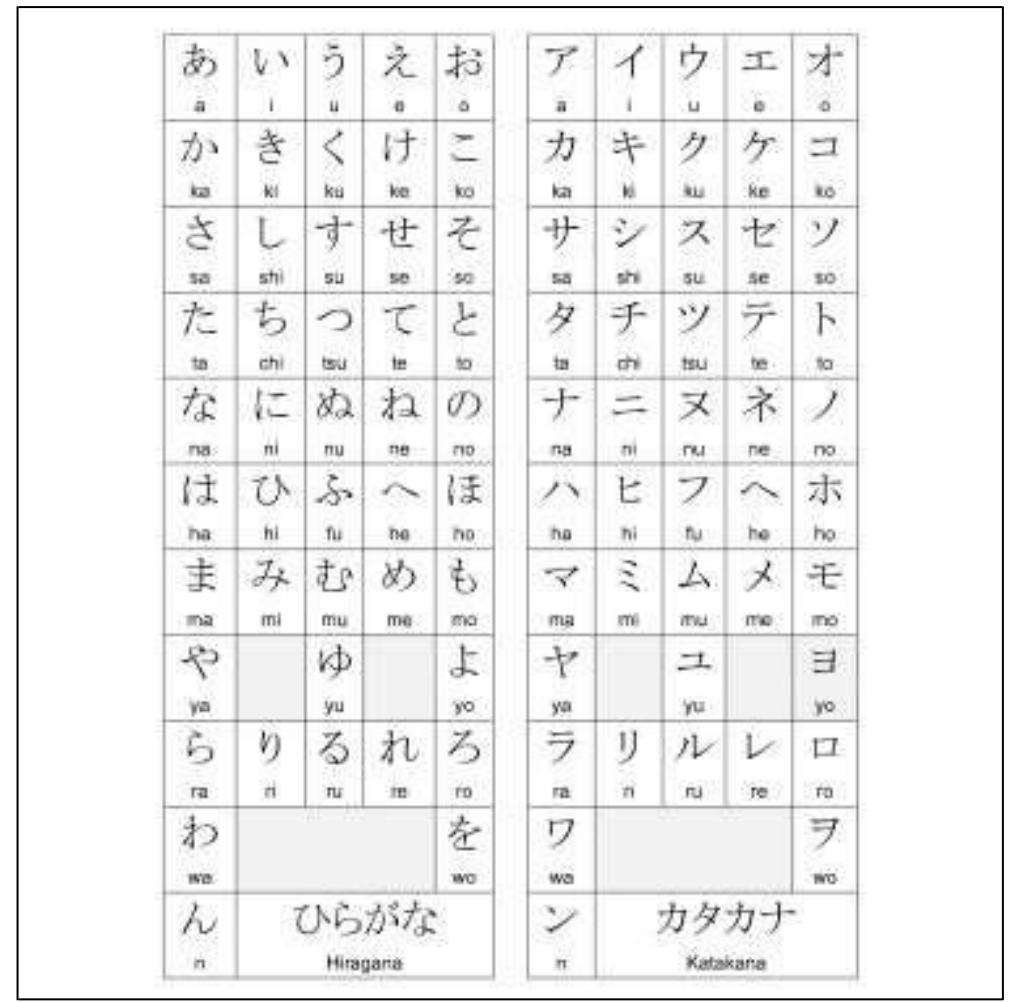

Gambar 3. Aksara Katakana dan Hiragana [6]

\section{b. Huruf Yoon}

Bunyi Yoon adalah bunyi huruf Hiragana Katakana dasar dengan menambahkan huruf ya, yu dan yo yang ditulis di sebelah kanan huruf dasar dengan ukuran yang lebih kecil. Penulisan antara huruf ya, yu dan yo yang ditulis dengan ukuran yang sama dan berbeda dengan huruf dasar memiliki perbedaan, misalnya huruf ひや dibaca hiya sementara huruf ひや dibaca hya. Huruf dasar yang menggunakan huruf ya, yu dan yo yaitu huruf dasar urutan kedua, seperti huruf ki, shi, chi, ni, hi, mi dan ri.

\subsection{Game Edukasi}

Game edukasi adalah hiburan yang dirancang untuk mengajarkan topik/subyek tertentu atau membantu seseorang mempelajari keterampilan melalui apa yang dimainkan [7]. Keunggulan game edukasi dibandingkan metode pembelajaran konvensional diantaranya mampu meningkatkan kemampuan daya ingat anak melalui objek berupa gambar atau animasi yang terdapat dalam game sehingga materi pelajaran dapat disimpan dalam jangka waktu yang lebih lama dibandingkan metode pembelajaran konvensional [8].

\section{Hasil dan Pembahasan}

Game Edukasi Mengenal Huruf Katakana dan Hiragana dapat dijalankan pada smartphone dengan sistem operasi Android minimal versi Android 2.2 (Froyo : Frozen Yoghurt). Hasil perancangan berupa screenshoot dari game serta hasil penilaian aspek pada game oleh reponden, dipaparkan pada bab hasil dan pembahasan ini. 


\subsection{Tampilan Game Edukasi Mengenal Huruf Katakana dan Hiragana}

Subbab ini membahas beberapa tampilan utama dari hasil perancangan Game Edukasi Mengenal Huruf Katakana dan Hiragana.

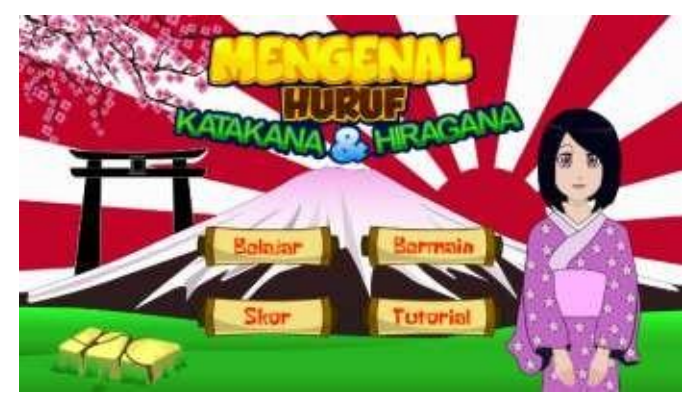

Gambar 4. Scene Menu Utama

Gambar 4 merupakan tampilan menu utama Game Mengenal Huruf Katakana dan Hiragana, dimana terdapat empat pilihan menu yaitu menu belajar, bermain, tutorial dan skor.

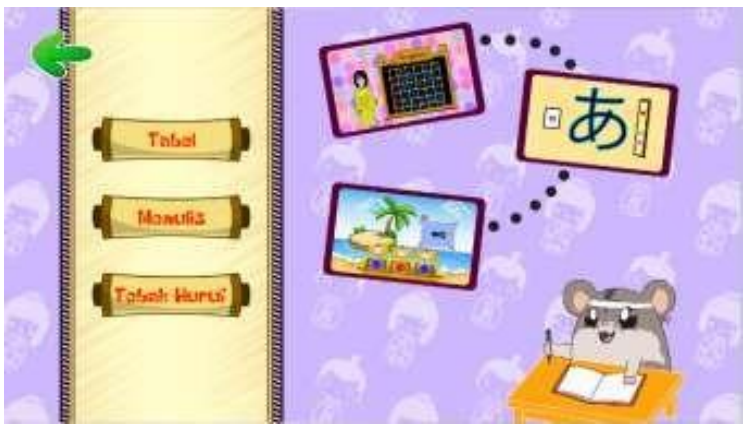

Gambar 5. Scene Belajar

Gambar 5 merupakan tampilan pilihan menu utama belajar. Terdapat tiga buah pilihan belajar diantaranya tabel untuk melihat tabel huruf, menulis untuk berlatih menulis huruf dan tebak huruf untuk latihan menghafal huruf.

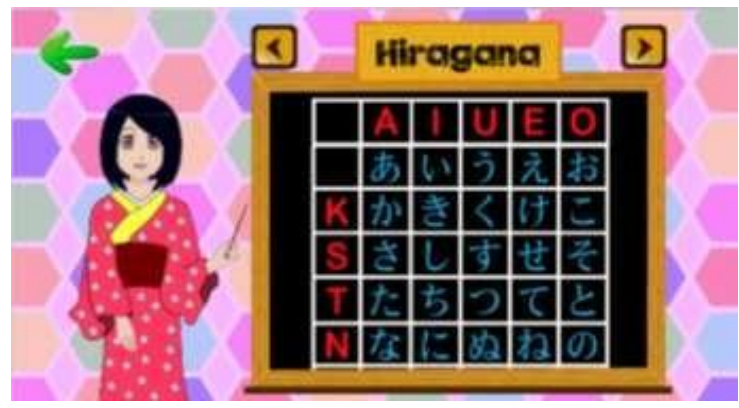

Gambar 6. Scene Tabel

Gambar 6 merupakan tampilan pilihan menu belajar tabel. Pengguna dapat melakukan scroll pada tabel untuk melihat keseluruhan tabel. Gambar 7 merupakan tampilan pilihan menu belajar menulis. Pengguna dapat membuat garis dengan melakukan handwriting serta terdapat tanda acuan dalam menulis. Gambar 8 merupakan tampilan pilihan menu belajar tebak huruf. Terdapat tiga buah tombol jawaban untuk menjawab huruf yang benar serta tanda yang menunjukkan jawaban benar atau salah. 


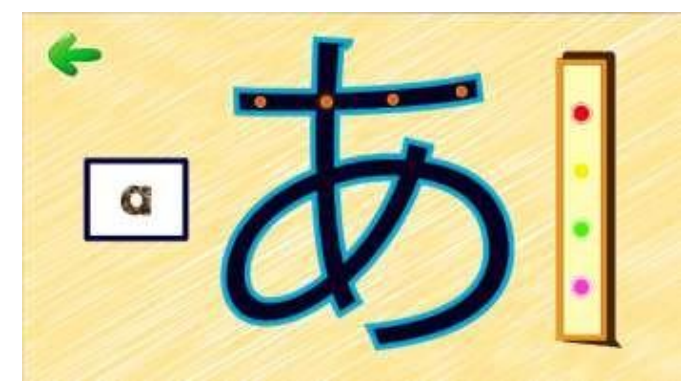

Gambar 7. Scene Tabel

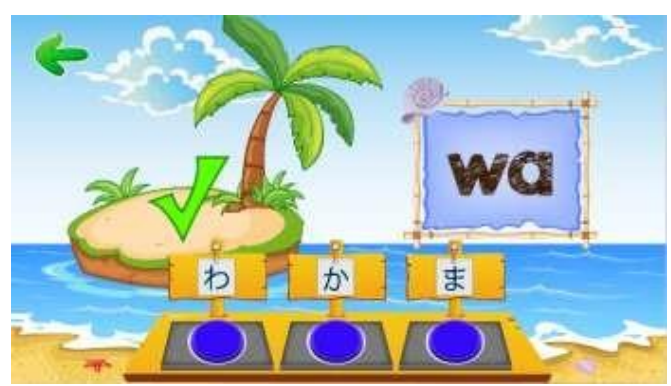

Gambar 8. Scene Tebak Huruf

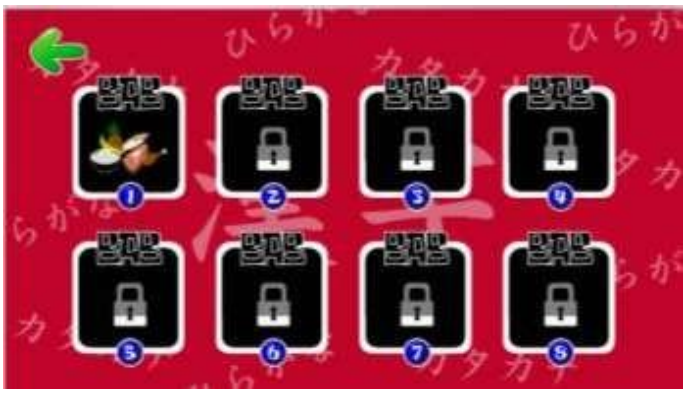

Gambar 9. Scene Level

Gambar 9 merupakan tampilan pilihan level dari menu utama bermain pada game. Scene ini berisikan delapan buah level dengan tema soal berupa kata yang berbeda tiap level.

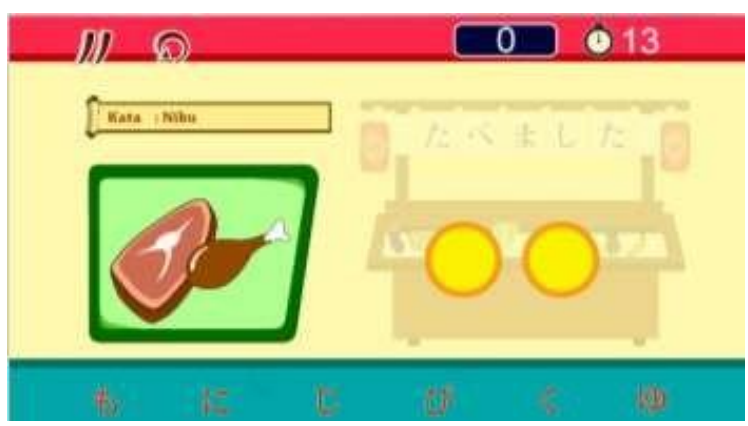

Gambar 10. Scene Gameplay

Gambar 10 merupakan tampilan scene saat bermain, dimana pada scene ini terdapat beberapa buah jawaban yang letaknya diacak kemudian user harus menyusun huruf sesuai dengan soal berupa kata yang muncul sebelum waktu habis. Gambar 11 merupakan tampilan pop up ketika jawaban yang dimasukkan benar. Terdapat tombol sound untuk mendengar bagaimana pengucapan dari kata tersebut. 


\subsection{Hasil Analisa}

Analisis terhadap game dilakukan dengan metode survey, penetapan variabel, pengumpulan data, penyajian data dan analisis untuk mengelola data. Masing-masing aspek diperoleh nilai persentasenya melalui analisis terhadap hasil kuesioner yang memiliki nilai tertinggi dan terendah dari masing-masing kriteria dalam aspek (sangat baik, baik, cukup baik dan kurang). Tabel 1 menunjukkan data responden.

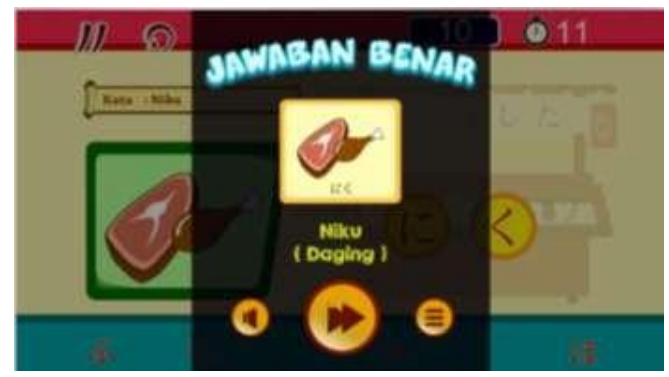

Gambar 11. Scene Jawaban Benar

\begin{tabular}{ccc}
\multicolumn{3}{c}{ Tabel 1. Data Responden } \\
\hline Usia (tahun) & Kelompok & Jumlah Responden \\
\hline $12-13$ & 1 & 14 \\
$16-17$ & 2 & 14 \\
$27-30$ & 3 & 2 \\
\hline
\end{tabular}

Total responden sebagai pemberi penilaian sebanyak 30 responden. Responden kelompok 1 dari siswa tingkat sekolah dasar berstandar internasional sebanyak 14 orang. Kelompok 2 dari siswa sekolah tingkat menengah atas sebanyak 14 orang. Kelompok 3 merupakan ahli dalam bahasa Jepang yaitu guru pelajaran bahasa Jepang sebanyak 2 orang.

\subsubsection{Aspek Grafis Visual}

Aspek grafis ditujukan untuk mendapatkan penilaian dari pengguna terhadap desain user interface game. Aspek grafis meliputi:
a. Visual (layout design dan warna)
b. Audio (sound effect dan background)
c. Media bergerak atau animasi

Berdasarkan Tabel 1 di atas, maka dapat ditarik kesimpulan sebagai berikut:

a. Jumlah responden sebanyak 30 orang.

b. Tidak ada responden yang memilih kurang menarik.

c. Responden yang memilih cukup menarik sebanyak 4 orang dan memiliki persentase sebesar $(4 / 30)^{*} 100 \%=13.33 \%$

d. Responden yang memilih menarik sebanyak 24 orang dan memiliki persentase sebesar $(24 / 30) * 100 \%=80 \%$

e. Responden yang memilih sangat menarik sebanyak 2 orang dan memiliki persentase sebesar $(2 / 30)^{*} 100 \%=6.67 \%$

f. Aspek grafis game mendapat respon dari responden dengan jumlah persentase cukup menarik sebanyak $13.33 \%$, persentase menarik sebanyak $80 \%$ dan presentasi sangat menarik sebanyak $6.67 \%$. Berdasarkan hasil persentase yang sudah diperoleh, persentase tertinggi terdapat pada penilaian menarik, sehingga dapat disimpulkan bahwa grafis game ini menarik bagi pengguna.

Keseluruhan hasil penilaian berupa persentase pada aspek grafis game dapat digambarkan pada diagram sebagai berikut : 
Tabel 2. Penilaian aspek grafis visual

\begin{tabular}{lc}
\hline Penilaian & Jumlah Responden \\
\hline Kurang & - \\
Cukup & 4 \\
Baik & 24 \\
Sangat Baik & 2 \\
\hline
\end{tabular}

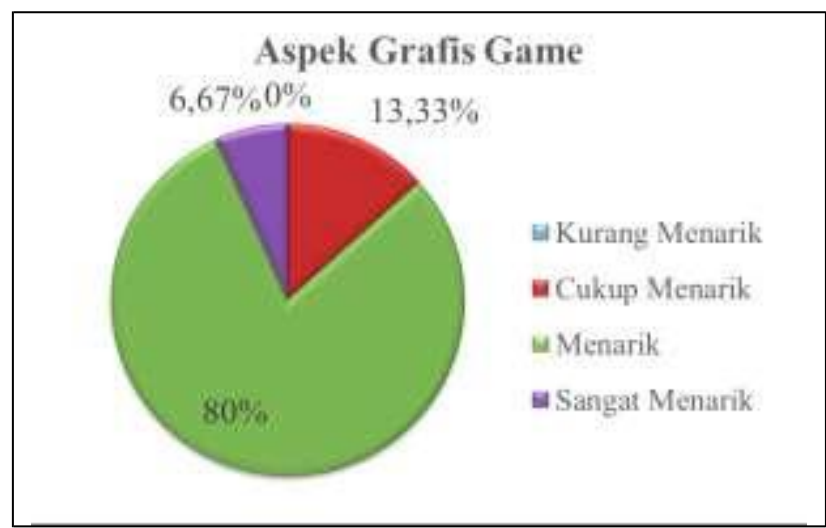

Gambar 12. Diagram aspek grafis game

Perbandingan persentase penilaian pada aspek grafis game dapat dilihat pada Gambar 12. Skor penilaian menarik dengan warna hijau memiliki daerah yang lebih luas pada diagram dibandingkan dengan penilaian lainnya yaitu sebesar $80 \%$.

\subsubsection{Aspek Rekayasa Perangkat Lunak}

Aspek rekayasa perangkat lunak ditujukan untuk mendapatkan penilaian dari pengguna terhadap kinerja game ketika dijalankan. Aspek rekayasa perangkat lunak meliputi:

a. Tingkat kemudahan dalam penggunaannya

b. Tingkat kompatibilitas dengan berbagai perangkat

c. Tingkat kehandalan aplikasi (tidak hang/ black screen/ force close)

Tabel 3. Penilaian aspek rekayasa perangkat lunak

\begin{tabular}{lc}
\hline Penilaian & Jumlah Responden \\
\hline Kurang & - \\
Cukup & 6 \\
Baik & 19 \\
Sangat Baik & 5 \\
\hline
\end{tabular}

Berdasarkan Tabel 3 di atas, maka dapat ditarik kesimpulan sebagai berikut:

a. Jumlah responden sebanyak 30 orang.

b. Tidak ada responden yang memilih kurang baik.

c. Responden yang memilih cukup baik sebanyak 6 orang dan memiliki persentase sebesar $(6 / 30)^{\star} 100 \%=20 \%$

d. Responden yang memilih baik sebanyak 22 orang dan memiliki persentase sebesar $(19 / 30)^{*} 100 \%=63.33 \%$

e. Responden yang memilih sangat baik sebanyak 5 orang dan memiliki persentase sebesar $(5 / 30)^{*} 100 \%=16.67 \%$ 
f. Aspek rekayasa perangkat lunak memperoleh respon dari responden dengan jumlah persentase cukup baik sebanyak $20 \%$, persentase baik sebanyak $63.33 \%$ dan persentasi sangat baik sebanyak $16.67 \%$. Berdasarkan hasil persentase yang sudah diperoleh, persentase tertinggi terdapat pada penilaian baik, sehingga dapat disimpulkan bahwa game ini dapat berjalan dengan baik ketika dimainkan.

Keseluruhan hasil penilaian berupa persentase pada aspek rekayasa perangkat lunak dapat digambarkan pada diagram sebagai berikut:

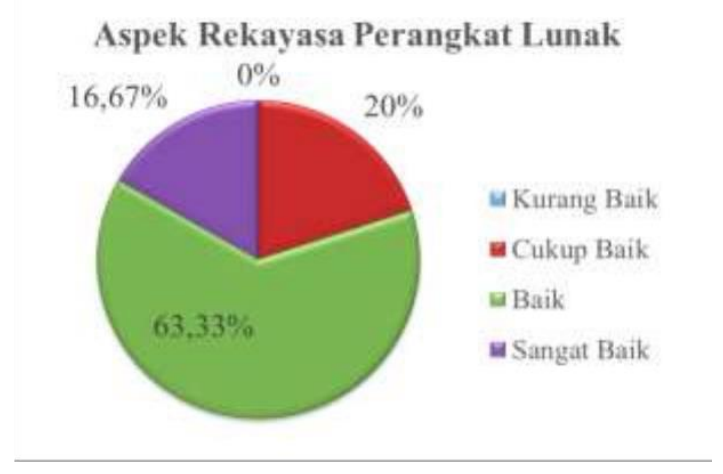

Gambar 13. Diagram aspek rekayasa perangkat lunak

Perbandingan persentase penilaian pada aspek rekayasa perangkat lunak dapat dilihat pada Gambar 13. Skor penilaian baik dengan warna hijau memiliki daerah yang lebih luas pada diagram dibandingkan dengan penilaian lainnya yaitu sebesar $63.33 \%$.

\subsubsection{Aspek Entertainment}

Aspek Entertainment ditujukan untuk mendapatkan penilaian dari pengguna terhadap sisi hiburan yang dirasakan. Aspek entertainment meliputi:

a. Tingkat kesulitan permainan

b. Media hiburan yang menyenangkan

c. Alur permainan yang jelas

Tabel 4. Penilaian aspek entertainment

\begin{tabular}{lc}
\hline Penilaian & Jumlah Responden \\
\hline Kurang & - \\
Cukup & 1 \\
Baik & 20 \\
Sangat Baik & 9 \\
\hline
\end{tabular}

Berdasarkan Tabel 4 di atas, maka dapat ditarik kesimpulan sebagai berikut:

a. Jumlah responden sebanyak 30 orang.

b. Tidak ada responden yang memilih kurang baik.

c. Responden yang memilih cukup baik sebanyak 1 orang dan memiliki persentase sebesar $(1 / 30)^{*} 100 \%=3.33 \%$

d. Responden yang memilih baik sebanyak 20 orang dan memiliki persentase sebesar $(20 / 30)^{*} 100 \%=66.67 \%$

e. Responden yang memilih sangat baik sebanyak 9 orang dan memiliki persentase sebesar $(9 / 30)^{*} 100 \%=30 \%$

f. Aspek entertainment memperoleh respon dari responden dengan jumlah persentase cukup baik sebanyak $3.33 \%$, persentase baik sebanyak $66.67 \%$ dan presentasi sangat baik sebanyak $30 \%$. Berdasarkan hasil persentase yang sudah 
diperoleh, persentase tertinggi terdapat pada penilaian baik, sehingga dapat disimpulkan bahwa game ini dapat memberikan hiburan kepada pengguna.

Keseluruhan hasil penilaian berupa persentase pada aspek entertainment dapat digambarkan pada diagram sebagai berikut:

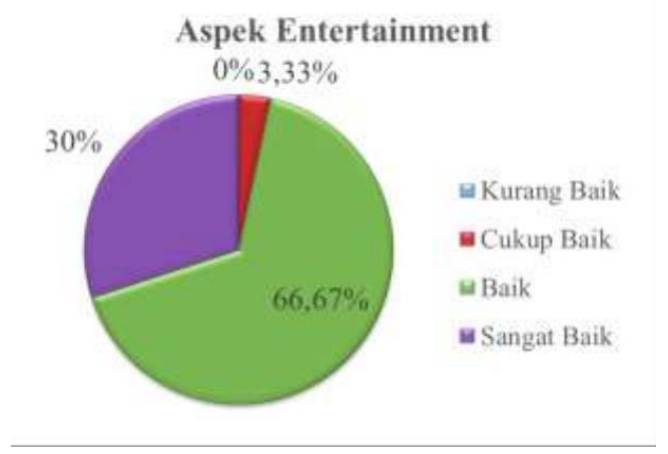

Gambar 14. Diagram aspek entertainment

Perbandingan persentase penilaian pada aspek entertainment dapat dilihat pada Gambar 14 . Skor penilaian baik dengan warna hijau memiliki daerah yang lebih luas pada diagram dibandingkan dengan penilaian lainnya yaitu sebesar $66.67 \%$.

\subsubsection{Aspek Content}

Aspek content ditujukan untuk mendapatkan penilaian dari pengguna terhadap tujuan utama dari pembuatan game ini yaitu manfaat edukasi/ pembelajaran yang didapatkan. Aspek content meliputi:

a. Pemahaman mengenai bentuk-bentuk huruf Katakana dan Hiragana

b. Pengetahuan mengenai tata tulis huruf Katakana dan Hiragana

Tabel 5. Penilaian aspek content

\begin{tabular}{lc}
\hline Penilaian & Jumlah Responden \\
\hline Kurang & 2 \\
Cukup & 6 \\
Baik & 18 \\
Sangat Baik & 4 \\
\hline
\end{tabular}

Berdasarkan Tabel 5 di atas, maka dapat ditarik kesimpulan sebagai berikut:

a. Jumlah responden sebanyak 30 orang.

b. Responden yang memilih kurang dipahami sebanyak 2 orang dan memiliki persentase sebesar $(2 / 30)^{*} 100 \%=6.67 \%$

c. Responden yang memilih cukup dipahami sebanyak 6 orang dan memiliki persentase sebesar $(6 / 30)^{*} 100 \%=20 \%$

d. Responden yang memilih dipahami sebanyak 18 orang dan memiliki persentase sebesar $(18 / 30)^{*} 100 \%=60 \%$

e. Responden yang memilih sangat dipahami sebanyak 4 orang dan memiliki persentase sebesar $(4 / 30)^{*} 100 \%=13,33 \%$

f. Aspek content mendapat respon dari responden dengan jumlah persentase kurang dipahami sebanyak $6.67 \%$, persentase cukup dipahami sebanyak $20 \%$, persentase dipahami sebanyak $60 \%$ dan persentase sangat dipahami sebanyak $13.33 \%$. Berdasarkan hasil persentase yang sudah diperoleh, persentase tertinggi terdapat pada penilaian dipahami, sehingga dapat disimpulkan bahwa game ini dapat membantu pengguna dalam memahami huruf Katakana dan Hiragana.

Keseluruhan hasil penilaian berupa persentase pada aspek content dapat digambarkan pada diagram sebagai berikut: 


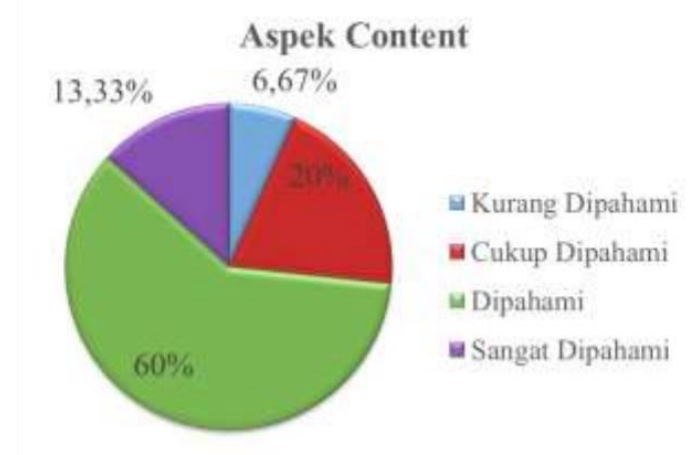

Gambar 15. Diagram aspek content

Perbandingan persentase penilaian pada aspek content dapat dilihat pada Gambar 15. Skor penilaian dipahami dengan warna hijau memiliki daerah yang lebih luas pada diagram dibandingkan dengan penilaian lainnya yaitu sebesar $60 \%$.

\section{Kesimpulan}

Game Edukasi Mengenal Huruf Katakana dan Hiragana memiliki tiga fitur pembelajaran terkait huruf Katakana dan Hiragana diantaranya tabel untuk melihat tabel huruf, menulis untuk berlatih menulis huruf dan tebak huruf untuk berlatih menghafal huruf serta fitur permainan yang dapat sekaligus mengevaluasi kemampuan pengguna. Tampilan grafis visual game dapat menarik perhatian pengguna sesuai dengan hasil kuesioner, 80 persen dari 30 responden memberi nilai menarik pada tampilan game. Selain itu game dapat menjadi hiburan yang menyenangkan berdasarkan hasil persentase 66.67 persen dari 30 responden memberi nilai baik pada alur game. Sebagai media pembelajaran, game ini dapat mendukung pemahaman terkait huruf Katakana dan Hiragana berdasarkan hasil persentase sebanyak 60 persen dari 30 responden menyatakan dapat memahami huruf Katakana dan Hiragana melalui game ini.

\section{Daftar Pustaka}

[1] S. Kurniah, "Faktor Kesulitan Belajar Huruf Hiragana pada Siswa Kelas X SMAN 3 Pekalongan," Semarang, 2013.

[2] A. Setiyawan, "Balinese Alphabet Sebagai Aplikasi Media Pembelajaran Aksara Bali Berbasis Android Mobile Platform," Denpasar, 2014.

[3] B. Belkhouche, N. S. Al Darei, S. A. S. Ali, S. H. Al Mandhari, and M. A. Al Mehairi, "Learning Arabic With Games," in International Conference on Computer Games, Multimedia \& Allied Technology (CGAT). Proceedings, 2014.

[4] M. P. J. Habgood and S. E. Ainsworth, "Motivating Children to Learn Effectively: Exploring the Value of Intrinsic Integration in Educational Games," J. Learn. Sci., 2011.

[5] "http://www.stiks-tarakanita.ac.id." [Online]. Available: http://www.stiks-tarakanita.ac.id. [Accessed: 10-Oct-2014].

[6] "http://kisah-anak-kost-kikos.blogspot.com." [Online]. Available: http://kisah-anak-kostkikos.blogspot.com. [Accessed: 10-Oct-2014].

[7] E. Millan, C. Carmona, and R. Sanchez, MITO: an educational game for learning Spanish orthography. Departamento de Lenguajes y Ciencias de la Computacion, Universidad de Malaga, 2014.

[8] "http://www.caspianlearning.co.uk/downloads/documents/Whtp_caspian_games_1.1.pdf." [Online].

Available: http://www.caspianlearning.co.uk/downloads/documents/Whtp_caspian_games_1.1.pdf. [Accessed: 13-Oct-2014]. 